\title{
HOW DO BINUS UNIVERSITY UNDERGRADUATE STUDENTS VALUE ENGLISH IN THE GENERAL, ACADEMIC, AND ELT CONTEXT?
}

\author{
Almodad B. Asmani \\ English Department, Faculty of Language and Culture, Bina Nusantara University, \\ Jln. Kemanggisan Ilir III No. 45, Kemanggisan/Palmerah, Jakarta Barat 11480 \\ aasmani@binus.edu
}

\begin{abstract}
Article explored the issues of the reasons and ways Indonesian undergraduate students taking English subjects at Binus University valued English, particularly in relation to its roles and influences as the dominant language and as the world's lingua franca, and how these could give impacts on the ELT (English Language Teaching) purposes at Binus University. The study used the quantitative approach to find out the pattern of the ways they valued English in the general, academic and ELT contexts. The analysis of the quantitative results showed that there was a tendency that non-computer students value English relatively higher than computer students in terms of linguistically imperialistic ideas and macroacquisition views, while English itself tended to be respected by all students for both reasons of material/non-material benefits as well as international influences. In summary, teacher resources, teaching techniques, curriculum design, material content and assessment format should put these findings into consideration so as to make the best teaching methodology for ELT practices at Binus University.
\end{abstract}

Keywords: English Values, Students

\begin{abstract}
ABSTRAK
Artikel menjelaskan alasan dan cara mahasiswa yang mengambil mata kuliah bahasa Inggris di Universitas Bina Nusantara dapat menghargai bahasa Inggris, khususnya terkait dengan peran bahasa Inggris sebagai bahasa pergaulan internasional, serta bagaimana hal ini berdampak pada tujuan pengajaran bahasa Inggris (ELT) di Binus. Penelitian menggunakan metode kuantitatif guna mendapatkan pola atau cara mahasiswa menghargai bahasa Inggris secara umum, akademik, dan yang terkait dalam konteks ELT. Hasil analisis menunjukkan bahwa terdapat tendensi mahasiswa jurusan non-komputer menghargai bahasa Inggris lebih tinggi dari pada jurusan komputer untuk bidang linguistic imperialistic dan macroacquisition, sementara bahasa Inggris sendiri dihargai oleh semua jurusan, baik untuk alasan keuntungan material/non-material dan pengaruh internasional. Disimpulkan, pengajar, teknik mengajar, kurikulum, material, dan format ujian harus memperhatikan temuan ini sehingga pengajaran bahasa Inggris yang paling tepat di ELT dapat dilaksanakan.
\end{abstract}

Kata kunci: Nilai Bahasa, Bahasa Inggris, mahasiswa 


\section{INTRODUCTION}

Article explores the issues of why and how Indonesian undergraduate students learning English subjects at Binus University value the English language, particularly in relation to factors of linguistically imperialistic ideas and macroacquisition influences, and how these can give impacts on the ELT (English Language Teaching) purposes at Binus University. A large number of Binus University students of different majors are taking English subjects as part of their required credit scheme at their own faculties. There seems to some pedagogic problems that hinder their success in learning English at Binus University. Certainly, these students have their own reasons and purposes as well as preferred ways to learn English in the educational contexts at Binus University. The research paper describes what these possible reasons might be and what ways they value English in this regard, and how these perspectives can be linked to some teaching approaches in ELT pedagogy at Binus University. The research refers to two conflicting perspectives of "linguistic imperialism" as proposed by Phillipson (1992) and of international influences as proposed by MacKay (2003).

The purpose of the research is to find out whether the students' interests in learning English subjects at Binus University is the result of the consideration of rewards and benefits that English can bring into their lives, such as in economic, communicative (here meaning communication and transport), cultural, social and educational contexts, and if not, for what and why. The study also tries to find out how these students view some teaching approaches in the ELT contexts at Binus University as the result of their valuing English in this regard. Therefore, the research project aims to answer several research questions, namely: (1) what is the rationale of learning English at Binus University from the students' perspectives?; (2) in what ways do these students learning English subjects at Binus University value English?; and (3) how are these ways of valuing English in this regard related to the teaching and learning process of ELT contexts at Binus University?

The study has some academic significance in a way that it provides the detailed description of the reasons and ways Binus University students value English and of the teaching approaches that should be conducted in this regard. The knowledge can provide resourceful information for ELT contexts at Binus University in terms of: (1) the teacher resources of native or non-native speakers of English; (2) the curriculum design of the academic or business goals; (3) the teaching methodology of CLT (Communicative Language Teaching) approach or Grammar-based instruction; and (4) the assessment issue of formative or summative format.

By the results of the research, I could find the closer link and match between the theoretical foundations of ELT pedagogy and the dynamic needs and demands of the Indonesian students studying English at Binus University.

Phillipson introduces the term "English linguistic imperialism" and defines it as the condition where "the dominance of English is asserted and maintained by the establishment and continuous reconstitution of structural and cultural inequalities between English and other languages" (1992: 47). Structural here refers to "material properties (for example, institutions, financial allocations)" (p. 47), and Cultural refers to "immaterial or ideological properties (for example, attitudes, pedagogic principles)" (p. 47). In his perspective, English linguistic imperialism is considered as a sub-type of 'linguicism', which he defined as 'ideologies, structures, and practices which are used to legitimate, effectuate, and reproduce an unequal division of power and resources (both material and immaterial) between groups which are defined on the basis of language' (1992: 47).

One of the legitimation of English linguistics imperialism, in his perspective, is in the area of pedagogy (professionalism), in which ELT, together with its methods, techniques, and procedures, contributes to maintain the structural and cultural inequalities of linguicism. In his arguments, ELT basically fulfills three specific functions to serve the 'State'. First, it has 'economic-reproductive' 
function, in which it helps the State to operate the technology in the nation by qualifying the people with English as the access language. Secondly, it also has 'ideological' function, where it provides people with the channel for modern ideas, such as interpersonal, social and cultural values that English brings with it. Thirdly, it has 'repressive' function, where English is the only choice as the medium of instruction in English classes and for other subjects. Therefore, in his consideration, ELT is closely linked to 'hegemony', where it is used to justify the use of English or the learning of English, which contribute to the maintenance of English as the dominant language.

McKay (2003) challenges the assumption that "interest in learning English is largely the result of linguistic imperialism" (p. 3). She argues that the dramatic change in the number of second language speakers of English around the world and the present cultural shift of the nature of English have resulted in the new nature of English as an international language. She argues that students choose to learn English because they will need it in 'multilingual context', where more and more individuals acquire English as the means of communication for inter/intranational purposes. In particular, she uses Brutt-Griffler terms 'macroacquisition' to refer to the condition where "many individuals in an existing speech community acquiring the language" (p. 2), resulting in the increasing number of bilingual users of English worldwide. The other reason why many individuals learn English, in her perspective, is they need to explain to others about their own country and cultural values for international relations, such as for commerce or business purposes.'

Hence, in McKay's point of view, English learning no longer needs to focus heavily on the concerns and cultures of inner circle countries, and as a result, learners do not need to 'internalize the cultural norms of the target language' (p. 3). Based on her arguments, she proposes new pedagogy of ELT by challenging some of the assumptions of typical ELT pedagogy, namely (p. 3): (1) Interest in learning English is largely the result of linguistic imperialism; (2) ELT research and pedagogy should be informed by native speaker models; (3) The cultural content for ELT should be derived from the cultures of native English speakers; and (4) The culture of learning that informs communicative language teaching (CLT) provides the most productive method for ELT.

In her journal, Celce-Murcia et al. (1997) discusses about some problems found in the CLT approach, which has been used quite extensively in various institutions, including at the university level. In my consideration, these problems are closely related with the ways students value English in its relation with what they can achieve after graduation.

In my research project, I will try to find out whether students' interests in learning English are the result of factors related to linguistically imperialistic ideas (as proposed by Phillipson and some other authors), or whether they have their own reasons and purposes in learning English which are not influenced by the promotion of the inner circle countries. Furthermore, I would like to find out how these students view the assumptions of the new ELT pedagogy (as proposed by McKay), as the result of the de-linking of English from Inner Circle countries and the increasing number of bilingual users of English in the Outer Circle.

\section{METHOD}

\section{The Nature of Knowledge and General Research Approach}

Instead of trying to find the 'universal laws' underpinning a social world (Cohen et al., 2000), I will focus on the general tendency of these students in valuing English in relation to its role as the dominant language and as the international language. After that, I will try to link their assumptions in this regard with some related approaches of ELT pedagogy. Thus, I will try to find out their pattern of responses to the statements that I will design in the instrument to reflect those assumptions. 
Based on the nature of this knowledge, my position in this research project is in the positivist/empiricist epistemology. This approach is more concerned with generalization, prediction and control. Based on the nature of my research, I will apply the approach of quantitative data gathering and analysis. By using a quantitative methodology in the project, I will focus on more context-free generalizations of the observed social phenomenon by examining the relationship of the variables. Here, I will rely on statistical results represented with numbers.

\section{Data Collection}

I will use survey questionnaires to collect the data, and my target population will be all undergraduate students who study English subjects at Binus University in the even semester of 2008/2009.

\section{Questionnaires}

To find out how these students value English, I will use arguments proposed by some authors who hold different perspectives. One holds the linguistically imperialistic ideas, and the other supports the macro-acquisition nature of English. Besides, I will also use arguments that are carefully considered as representing the underpinning principles of CLT approach, based on the ideas of some authors. This kind of questions will provide many possible reasons and purposes why these students learn English or why these students consider English important, as well as whether the current CLT approach has already been in line with the needs and demands of the learners.

I will give the statements in the form of questionnaires of predominantly selected-response questions with some open-ended items. The selected-response items enable me to maintain the precision and clarity of my research problems in a way that the possibility of the students to give answers or responses, which deviate from the real problems, can be put at a minimum level. It is very hard to control this in open-ended questions or interviews alone. Wiersma (1991) notes that "Selectedresponse items enhance consistency of response across respondents, data tabulation generally is straightforward and less time-consuming than for open-ended items” (p. 176). In my consideration, the pre-coded items also help students think about the reasons and purposes of learning English, which might already exist unconsciously in their minds. Furthermore, the statements that I will provide in the questionnaire are already thought of and formulated carefully to represent many possible reasons and purposes that best reflect how students value English in this matter.

Since I will measure how strong their average responses to each statement are, it asks for degrees of agreement. Here, I will use a kind of Likert scaling with five or more choices, ranging from 'Strongly Agree' to 'Strongly Disagree'. McDonough and McDonough (1997) note that each statement is related to each other, and the respondents' responses 'can be summed over the whole questionnaire' to produce a measure of strength. Due to some considerations of the high response rate, non-respondents' exclusion, the spread of respondents and reasonable costs, I will personally administer the questionnaire to the participants by asking the permission of time and opportunity from some English lecturers teaching their classes in the even semester of 2008/2009 across campuses at Binus University.

\section{Participants}

I will divide the participants into two groups of undergraduate students who take English subjects in the even semester of 2008/2009 at Binus University, which are: (a) Undergraduate students studying at Faculty of Computer Studies (80 students). (b) Undergraduate students studying at faculties of Non-Computer studies (80 students). (c) Undergraduate students studying at Faculty of Economics and Business (30 students). (d) Undergraduate students studying at Faculty of Communication and Multimedia (30 students). (e) Undergraduate students studying at Faculty of Language and Culture (20 students). 
These students are chosen as the participants in my research project due to some reasons. First, all students of non-English department studying at Binus University must take English as the core subjects. This results in a large number of English-studying students who need a special academic consideration and treatment to meet the aims and objectives as expected. Second, due to the fact that I am the coordinator of all English subjects at Binus University, I am in a better position to investigate any issue of the English subjects in terms of the appropriateness and quality of the materials given, the teaching methodology delivered and the curriculum designed.

Since there are subpopulations in the population to be sampled and due to the fact that it is not homogeneous, I will use the approach of stratified random sampling, where "all strata are represented in the sample, and the sample members are selected from each stratum at random" (Wiersma, 1991: 253). For allocation of sample size among strata, I will use proportional allocation method, where "the allocation of strata members in the sample is proportional to the numbers of members in the strata of the population” (Wiersma, 1991: 253).

\section{Data Analysis}

For quantitative analysis, I will use the ANOVA statistical analysis to test the hypotheses as follows: (1) Null Hypothesis 1: the responses means for Binus University students studying English at two different groups of faculty are equal. (2) Alternate Hypothesis 1: the responses means for Binus University students studying English at two different groups of faculty are not equal. (3) Null hypothesis 2: the responses means for Binus University students studying English in answering two different categories of question are equal. (4) Alternate hypothesis 2: the responses means for Binus University students studying English in answering two different categories of question are not equal.

My independent variables are the group difference (Faculties of Study) and the question categories (Linguistic Imperialism and Macroacquisition), and my dependent variable is the student's responses.

I choose the ANOVA statistical analysis due to various reasons. First, I use single items with Likert scale response format for measurement of the dependent variable (responses), whose data is on interval scale. Second, I will test the significance of the difference between the means of two independent samples under two independent variables, and the ANOVA statistical analysis applies in this procedure.

The data collected will be presented in a 2x2 Multifactor Analysis of Variance to find out the combined effect of the differences of the faculty groups and the question categories to the student's responses. By using the model, I will analyze: (1) whether there is a significant difference of the students' responses under two groups of faculty. (2) whether there is a significant difference of the students' responses in answering two categories of question.

If there is a significant difference in the first point, I will describe how different the students' responses are distributed under each group of faculty, and I will interpret the findings as to why they are different. If there is no significant difference in the first point, I will describe how similar the students' responses are distributed under each group of faculty, and I will interpret the findings as to why they are similar. If there is a significant difference in the second point, I will describe how different the students' responses are distributed under each category of question, and I will interpret the findings as to why they are different. If there is no significant difference in the second point, I will describe how similar the students' responses are distributed under each group of question, and I will interpret the findings as to why they are similar. 


\section{RESULTS AND DISCUSSION}

\section{Data Presentation}

Responses data of Binus University students from two faculty groups in valuing English under two categories of questions is presented in Table 1 below:

Table 1 Responses on English Value of Students from Two Faculty Groups under Two Question Categories

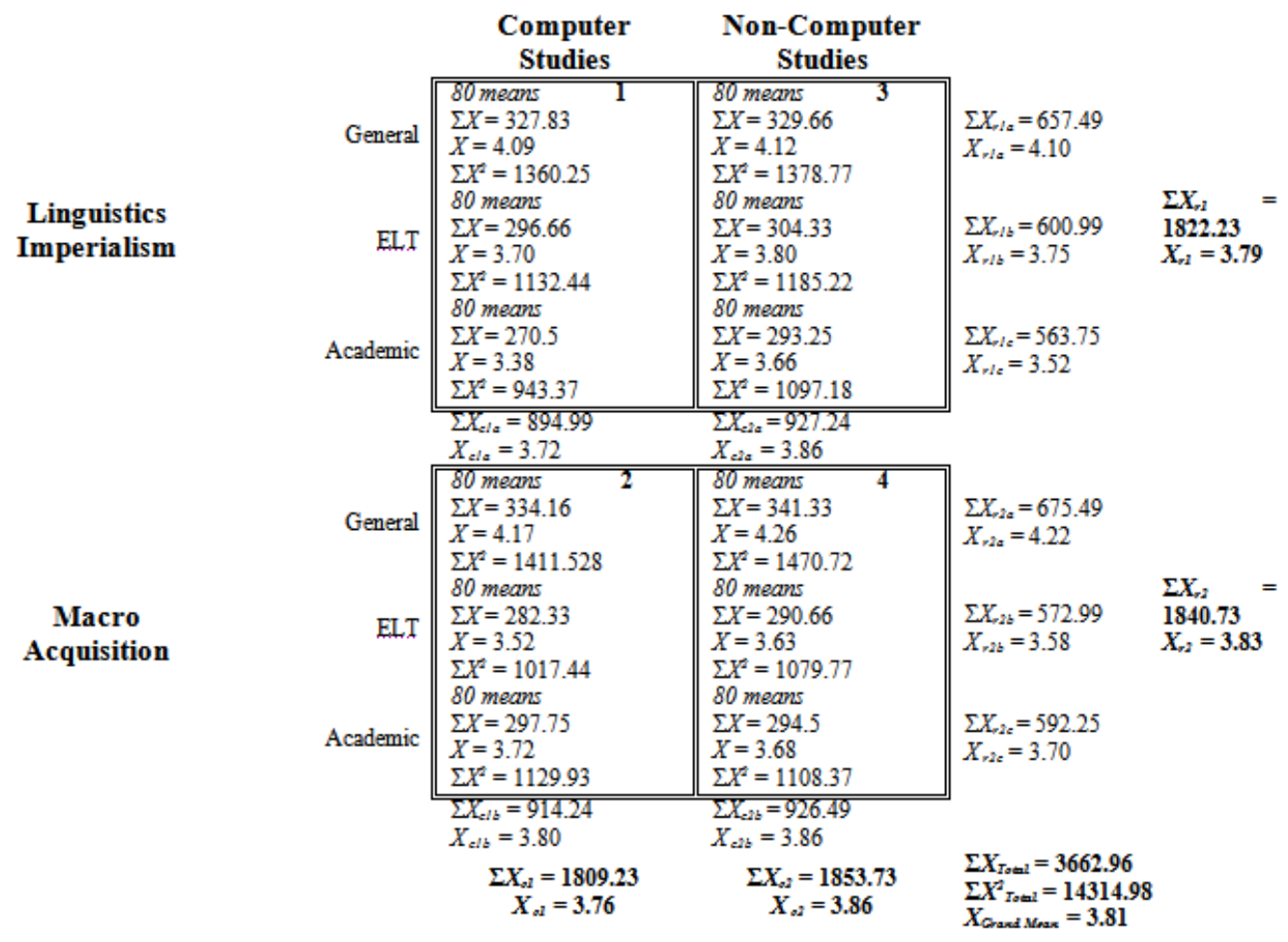

\section{Data Summary}

The responses data of the four student groups under the two faculty groups with two question categories is summarized in Table 2 below:

Table 2 Summary of a 2 x 2 Multifactor Analysis of Variance of Four Student Groups

\begin{tabular}{llllll} 
Source of Variance & SS & df & MS & F & Level of Significance \\
\hline \hline Between columns (Studies) & 2.06 & $\mathbf{l}$ & $\mathbf{2 . 0 6}$ & $\mathbf{7 . 3 5}$ & 0.01 \\
Between rows (Questions) & 0.36 & $\mathbf{l}$ & $\mathbf{0 . 3 6}$ & $\mathbf{1 . 2 8}$ & - \\
Column by rows (Interaction) & 67.329 & $\mathbf{l}$ & $\mathbf{6 7 . 3 2 9}$ & $\mathbf{2 4 0 . 4 6}$ & 0.01 \\
\hline Between groups & 69.749 & 3 & 23.246 & & \\
Within groups & 268.9 & $\mathbf{9 5 6}$ & $\mathbf{0 . 2 8}$ & & \\
\hline Total & 338.649 & & & &
\end{tabular}


Three $F$ ratios are listed in the table. To find the significance of each of these values, the writer consults the table of $F$ values in the appendix. To use the table, the writer uses the number of degrees of freedom associated with each $F$ ratio ( $d f$ for the numerator) and the number of $d f$ associated with the within-groups mean square ( $d f$ for the denominator).

The between-columns $F$ ratio is 7.35. Consulting the table, with 1 and $956 d f$, the writer finds that an $F$ ratio of 3.86 or more is needed for significance at the .05 level, and an $F$ ratio of 6.70 or more is needed at the .01 level. Because the obtained value of 7.35 is higher than the values shown on the table, the writer can conclude that the difference between the responses of the students from computer studies and from other studies is statistically significant.

The between-rows $F$ ratio is 1.28 . With the same $d f$ ( 1 and 956) on the table, the obtained value of 1.28 is lower than the $F$ ratio of both 3.86 (.05 level) and 6.70 (.01 level). The writer can conclude that the difference of the students' responses under linguistics imperialism questions and under macroacquisition questions is not statistically significant.

The column-by-rows $F$ ratio is 240.46 . With the same $d f$ ( 1 and 956$)$, the obtained value far exceeds both of the values on the table ( 3.86 and 6.70), and is thus significant at the .01 level. The writer can conclude that the difference between the responses of the computer students in answering Linguistics Imperialism and Macroacquisition questions and the responses of the non-computer students in answering Linguistics Imperialism and Macroacquisition questions is statistically significant.

\section{Data Interpretation of the First $F$ Ratio}

The first $F$ ratio (between columns) is significant and shows that the faculty groups differ significantly from one another in their effect on the responses of the students in answering the questions. The analysis is a comparison of the combined responses of groups 1 and $2(X=3.76)$ with the combined responses of groups 3 and $4(X=3.86)$. From the significance of this $F$ ratio, the writer can infer that the difference between the responses of the students from computer studies and those from other studies is beyond chance expectation. Because of the significance of the $F$ ratio for the group difference, the writer can conclude that undergraduate students of non-computer studies at Binus University tend to give a higher score in valuing English than computer students when they respond to both question categories of linguistic imperialism and macroacquisition.

\section{Linguistic Imperialism}

Under the domain of Linguistic Imperialism, the responses means of the students from computer studies (3.72) is lower than those from other studies (3.86). Generally, it shows that students from non-computer studies have given higher scores than students from computer studies in valuing English inherent with Linguistics Imperialism aspects in the general, ELT and academic contexts.

In the general contexts of Linguistics Imperialism, the average mean of the computer students is 4.09, and that of non-computer students is 4.12. It shows that students of non-computer studies at Binus University tend to give a more preference on English in terms of future career, educational levels, social status, world's information, excursions, and lifestyle that the inner circle countries can provide. However, students of computer studies also give a high value (4.09) towards English in this matter. So the writer can say that students of both groups tend to agree that English is appreciated for what it can bring to them in their lives in terms of material, educational, social and cultural benefits.

In the ELT context of Linguistics Imperialism, the average mean of the computer students is 3.70, and that of non-computer students is 3.80. Both means are under 4 (agreement level), but show a trend towards agreement. This means the students of both studies tend to agree (though not fully) that 
ELT should be inherent with the presence of native-speaking teachers, English-speaking culture-based materials and communicative language teaching (CLT) approach in the classroom. In the data, those of the non-computer studies tend to give a higher score on valuing English with linguistic imperialistic ideas in ELT context than those of computer studies.

In the academic context of linguistic imperialism, students of non-computer studies have given English a higher score (3.66) than those of the computer studies (3.38). However, both groups still value English in this matter under the score of 4 (agreement level). Students of computer studies are tend to be not fully in agreement (score 3.38) with the situation that English in the academic settings, such as seminars, workshops, etc should be rendered with the direct writing style of the papers, native-like proficiency of the speakers, participants and writers, while students of noncomputer studies tend to render higher agreement with the situation (score 3.66).

\section{Macroacquisition}

Under the domain of macroacquisition, the responses means of the students from computer studies (3.80) is lower than those from other studies (3.86). Generally, it shows that students from noncomputer studies have given higher scores than students from computer studies in valuing English inherent with macroacquisition aspects in the general, ELT and academic contexts.

In the general context of macroacquisition, the responses mean of the computer students (4.17) is lower than that of non-computer students (4.26). However, students of both groups tend to give a high score (score 4 and above). This shows that they tend to have a clear preference towards English with the benefits of international economic transactions, international research, international people, international source of information, international excursions and international cultures that English can bring with. Students of non-computer studies tend to value English more in this matter (4.26) than computer students (4.17).

In the ELT context of macroacquisition, the responses mean of the computer students (3.52) is far less than that of the non-computer students (3.63). However, students of both groups tend to give a lower score than score 4 (agreement level). It seems that they tend to give responses towards agreement (though not fully) to the aspects of macroacquisition inherent in ELT, such as the presence of the international English teachers, the multinational culture-based materials and the more grammarbased approach in the classroom. Students of computer studies tend to far less agree with the situation (3.52) than students of non-computer studies (3.63).

In the academic context of macroacquisition, the responses means of the computer students show a bit higher score (3.72) than that of non-computer students (3.68). However, students of both groups give a score that is below 4 (agreement level). This means that students of both groups tend to give responses towards agreement (though not fully) with the situation that under academic contexts, such as seminars, workshops, etc, English should be rendered with the aspects of a freer writing style of the papers presented, international accents and language styles of the speakers, participants and authors. The students of the computer studies give a higher score in valuing English in this matter (3.72) than the students of the non-computer studies (3.68).

\section{Data Interpretation of the Second $F$ Ratio}

The second $F$ ratio (between rows) is not significant and shows that the two questions categories do not differ significantly from one another in their effect on the responses of the students. This analysis, a comparison of the combined responses of groups 1 and $3(X=3.79)$ with the combined responses of groups 2 and $4(X=3.83)$, was not statistically significant, so the writer can conclude that the difference between the students' responses to Linguistic Imperialism questions 
versus those to Macroacquisition questions is not statistically significant. Both groups of students give an average score below 4 (agreement level) to both types of questions, so both of them value English with relatively the same trend of neutrality-towards-agreement level in terms of either linguistic imperialism and macro acquisition aspects.

\section{General Context}

Under the general contexts of both linguistic imperialism and macroacquisition categories, the students give the average score above 4 (agreement level). So, they generally think that English is much appreciated for both the aspects of linguistic imperialism and macroacquisition. They consider that English can bring them the benefits of financial, educational, social, informational, travel and cultural rewards of the Inner Circle. However, they also consider that English is appreciated for its advantages in multinational business transactions, wider knowledge, international relations, multisource information, international excursions, and multicultural experiences.

\section{ELT Context}

Under the ELT contexts of both categories of questions (linguistic imperialism and macroacquisition), both groups of students give the average scores between 3.5 and 3.8, which indicates that they tend to show a neutrality-towards-agreement trend with the context of ELT inherent with either linguistic imperialism or macroacquisition features. English in the ELT context of linguistic imperialism involves the roles of the native-speaking teachers, west culture-oriented materials, and the promoted CLT (Communicative Language Teaching) approach. English in the ELT context of macroacquisition involves the roles of international teachers of English, multicultural content-based materials, and form (rather than meaning)-based teaching approach. Due to the insignificance of the between-rows $F$ value, the writer thinks that there are some aspects of either linguistic imperialism or macroacquisition that students tend to agree (though not fully) if these are to be integrated into ELT context.

\section{Academic Context}

Under the academic context of both linguistic imperialism and macroacquisition, both groups of students render the average scores between 3.38 and 3.72, which again show that they tend to give a neutrality-towards-agreement response that academic context be influenced with all aspects of both linguistic imperialism and macroacquisition. The academic context with linguistic imperialism includes the direct style in writing papers, the native-like proficiency of the presenters, participants and authors. The academic context with macroacquisition includes the freer style of writing papers, international accents and language styles of the presenters, participants and authors. With the insignificance of the $F$ value (between-rows), the writer concludes that students tend to agree (though not fully) that some aspects or more of either linguistic imperialism or macroacquisition be integrated in the academic settings.

\section{Data Interpretation of the Third $F$ Ratio}

The third $F$ ratio shows the interaction effect between the two variables: the faculty groups' difference and the questions categories' difference. The significance of the $F$ ratio in this case means that the effect of the questions categories on the students' responses depends on which source of the two faculty groups they come from.

Among the students from computer studies, the difference between macroacquisition and linguistic imperialism is 0.08 point $(3.8$ - 3.72). Among the students of non-computer studies, the difference between macroacquisition and linguistic imperialism is none or 0 point $(3.86-3.86)$. 
Because the $F$ test indicates that the interaction is significant, the writer can conclude that macroacquisition questions makes more influence when responded by students of computer studies than when responded by students of non-computer studies. This means that for students of computer studies, English is valued more on the macroacquisition aspects than on the linguistic imperialism aspects.

\section{Macroacquisition - General Context}

Under the general context, for students of computer studies, English is generally given more values on aspects of:

- international business transactions rather than of financial rewards of the inner circle

- wider and more intensive level of knowledge rather than of educational status

- international network rather than of higher social status

- multi-source information rather than of inner-circle information

- international visits rather than of inner-circle visits

- multicultural environment rather than of inner-circle environment

\section{Macroacquisition - ELT Context}

Under the ELT context, for students of computer studies, English is generally given more values on the aspects of:

- professional teachers of international background rather than of inner circle countries' background

- multicultural-based materials rather than inner circle-based materials

- non-CLT approach (such as grammar-based) rather than CLT approach

\section{Macroacquisition - Academic Context}

Under the academic context, for students of computer studies, English is generally given more values on the aspects of:

- internationally appropriate style in writing papers rather than the inner circle standard style

- international accents of the interlocutors rather than inner circle accents of the interlocutors

- international gestures and styles in speaking rather than inner circle gestures and styles in speaking

- international authors of the academic papers rather than the inner circle authors

\section{CONCLUSIONS}

The first quantitative finding shows that the average responses of the non-computer students is statistically different from those of the computer students, with the tendency that non-computer students respect English relatively higher than the computer students in valuing the language of innercircle and international influences. The second quantitative finding shows that there is no significant difference between all students' average responses to linguistic imperialism questions and those to macroacquisition questions. This means that English tend to be respected by all students both for material/non-material benefits as well as for its universality. The third quantitative finding shows that the effect of English as the superior language and of English as the global language on the students' average responses depend on the number of the responses of one faculty group they belong to. In this case, the responses to macroacquisition questions become higher and clearer if deriving from the number of computer students. This means the more computer students respond to macroacquisition questions, the more likely their average responses to English as the universal language becomes more apparent. 


\section{Results of the Study}

The findings of the research paper have brought some valuable input and implications for the ELT contexts at Binus University, namely: (1) The preference for ELT teachers of native or nonnative speakers English of the inner circle countries is generally of no big issue for the Binus University undergraduate students as they are more opt for any ELT teachers who are professional, communicative and likable; (2) The design for the ELT curriculum can be directed to a more balanced goal of academic and business/social aspects, as these students put the strong emphasis and demands on communicative-based activities of the daily needs rather than form-based exercises; and (3) the teaching methodology of CLT (Communicative Language Teaching) approach has been given much appreciation by the Binus University students, and thus needs to be highly regarded as an alternative to the common approach of grammar-based instruction.

\section{REFERENCES}

Celce-Murcia, M., Dornyei, Z., \& Thurrell, S. (1997). Direct approaches in L2 instruction: a turning point in communicative language teaching? TESOL Quarterly, 31 (1), 141 - 152.

Cohen, L., L. Manion, et al. (2000). Research Methods in Education. London: Routledge Farmer.

Kachru, B. B. (1986). The Alchemy of English. Oxford: Pergamon Press.

McDonough J., and McDonough S. (1997). Research Methods for English Language Teachers. UK: Arnold.

McKay, S. L. (2003). Toward an appropriate EIL pedagogy: re-examining common ELT assumptions. International Journal of Applied Linguistics. 13 (1), 1-22.

Phillipson, R. H. L. (1992). Linguistic Imperialism. Oxford University Press.

Usher, R. (1996). A critique of neglected epistemological assumptions of educational research. In D. Scott and R. Usher (eds), Understanding educational research. London: Routledge.

Wiersma, W. (1991). Research Methods in Education. USA: Allyn and Bacon. 